\title{
Stakeholders Participation and Sustainability of Corporate Social Responsibility Programmes in Ghana: A Study of AngloGold Ashanti Mine in Obuasi
}

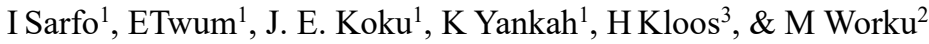 \\ ${ }^{1}$ Department of Environment \& Development Studies, Central University College, Accra, Ghana \\ ${ }^{2}$ Department of Civil \& Environmental Engineering, University of Connecticut, USA, \\ ${ }^{3}$ Department of Epidemiology and Biostatistics, University of California, San Francisco, USA \\ Correspondence: I Sarfo, Department of Environment \& Development Studies, Central University College, Accra, \\ Ghana. E-mail: sarfoiike@yahoo.com
}

Received: January 4, 2016 Accepted: January 24, 2016 Online Published: February 20, 2016

doi:10.5539/enrr.v6n1p59 URL: http://dx.doi.org/10.5539/enrr.v6n1p59

\begin{abstract}
Corporate Social Responsibility (CSR) has gained tremendous attention in the policy implementation of some organizations. National governments and societies have developed keen interest in the operations of organizations under this jurisdiction. Therefore, companies may not only be profit oriented but would seek to enhance the welfare of the people as they operate in a more sustainable way without harming the environment. It is on this premise that this article attempts to assess stakeholder participation and sustainability of corporate social responsibility programmes implemented by AngloGold Ashanti in Obuasi, Ghana.

CSR programmes initiated by AGA-Obuasi are categorized into four main areas: Community Health and Malaria Control Programme, Social Infrastructure, Education and Sports as well as Art, Culture \& Heritage programmes (AngloGold Ashanti, 2013). Activities of the mines affect Obuasi and their allocated unit areas environmentally, socially, economically and culturally and hence, the company is not only profit oriented but has assumed responsibility of developing the community through CSR and the reclamation bond or process.

CSR programmes are undertaken voluntarily by the mine corporation to facilitate its operations. CSR policies, plans, program and projects are broad and hence, the study was conducted mainly to assess stakeholder participation and sustainability. The relevant stakeholders in various communities in the AGA-Obuasi operational area were involved in the formulation and implementation of CSR programmes through consultative committee meetings, community/public meetings in various allocated communities. Program were formulated and implemented based on request from host communities.
\end{abstract}

Keywords: Corporate Social Responsibility, Sustainability, Reclamation bond, Community consultative committees, Voluntary initiatives, AngloGold Ashanti Obuasi Mines, Ghana

\section{Introduction}

Corporate Social Responsibility (CSR) has several definitions emanating from different international bodies, scholars, business organizations and so on. CSR can be defined as the continuing commitment by business to adhere to acceptable ethical standards and contribute to social, and economic development while seeking to enhance the quality of life and welfare of the workforce and their families as well as of local communities in which they operate (WBCSD, 2000). Based on this definition, companies or business organizations should not solely be profit-oriented but contribute voluntarily in instances when they are not obliged by any legal instrument to socio-economic development of the area of operations, enhancing the welfare of the local people and the sustainability of the natural environment, by operating in an efficient, transparent and environmentally friendly manner (McElroy \& Engelen, 2012).

In recent years, many companies around the world have integrated or employed the Corporate Social Responsibility (CSR) concept into their business policies, plans and programmes in an attempt to give back to the society in which they operate. Despite these efforts, there are no national legislative frameworks to ensure that, companies are obliged or mandated to embark on CSR as in the case of Ghana (Atuguba, 2006). Some 
multinational and multilateral companies have taken up the mantle voluntarily to make some commitments to enhance and develop the welfare of the people and communities in their areas of operations. Such commitments or voluntary initiatives embarked upon by some companies have gained much popularity in most countries (Hohnen, 2007).

AngloGold Ashanti is one of the multinational companies initiating such voluntary initiative in their quest to maximize economic profits but also to facilitate development (AngloGold Ashanti, 2013). Several scholars and researchers have studied about the subject area and impacts of the Mines on the Obuasi community. The objectives of the study are to;

- Determine the stakeholders involved in the formulation of CSR programmes

- Outline CSR programmes initiated by AngloGold Ashanti.

- Analyse the sustainability of CSR programmes, initiated by AngloGold Ashanti, thus, if these CSR programmes would run to enhance the welfare of the community if the Mines should shut down.

- $\quad$ Propose measures that can make these CSR programmes more effective based on findings.

The study will examine whether the policies are imposed on the people or reflect the interest of the people and communities. AGA as part of its safety operations, in exploiting minerals from the environment, developed a "reclamation bond process". This bond was meant to ensure that, AGA reclaims degradable lands and make it useful despite its deterioration of use for agricultural purposes.

Obuasi, known as "Sikakrom" or "Golden City", is a town in the southern part of the Ashanti region of Ghana. The capital lies south of the regional capital, Kumasi. Obuasi had a settlement population of about 168,641in 2010 (GSS, 2012). The mining industry gives Obuasi its cosmopolitan mosaic of cultures from all over the country, the African continent and beyond. It is recognized to be one of the richest gold mining areas in the world. In fact; Ghana was named the Gold-Coast because of the gold which was found in Obuasi.

\subsection{The Study Area}

The focus of this study is on the Obuasi Community, once the largest gold mines in Ghana, which now ranks second after Tarkwa Gold Mines (AngloGold Ashanti, 2007). The mines were initially owned by Ashanti Goldfields until April, 2004, when AngloGold Ashanti took over. AngloGold Ashanti is a multinational company which has its headquarters in Johannesburg, South Africa. It has about 21 operations in 11 countries, namely: Tanzania, Brazil, Australia, Argentina, Colombia, Guinea, Mali, Namibia, USA and Ghana, all of them involved in the extraction of metals and other mineral resources (AngloGold Ashanti, 2013).

The Obuasi municipality consists of thirty eight (38) electoral areas with sixty three (63) communities in it, of which AngloGold Ashanti operates in nineteen (19) of these electoral areas (AngloGold Ashanti, 2013). Most of the people living in the Obuasi municipality are into subsistent farming or mainly into Agriculture with few engaging themselves in petty trading and other economic activities.

\subsection{Statement of the Problem}

Many bilateral, multilateral and multinational companies are sited and operate in different parts of Ghana and outside the country. While perhaps most of these companies are mainly profit-oriented, some companies have incorporated CSR and other voluntary initiatives into their operations, mainly to improve the welfare of the people and development in the area of operations, as well as ensuring sound environmental management systems.

\subsection{Aim of the Study}

The main aim of the study is to assess stakeholder participation and sustainability of corporate social responsibility programmes initiated by AngloGold Ashanti in Obuasi, Ghana. The study is also to examine stakeholder commitment theory, CSR and its relation to social justice, thus, to explore corporate motives for human rights considerations.

The study is meant to go beyond existing knowledge about CSR programmes/projects initiated by AGA. It is therefore meant to explore more about this policy initiative, thereby establishing the fact on what happens on the ground and what is presented on paper by AGA. It is therefore meant to answer the following research questions;

(1) Who are the stakeholders involved in the formulation and implementation of CSR programmes by AGA?

(2) What programmes are initiated under CSR by AGA in the Obuasi municipality? 
(3) Are the interest of the people in these communities factored in the formulation of CSR programmes/projects or they are being imposed on them?

(4) How can these programmes be kept running if AGA closes or shuts down?

\subsection{Stakeholder Commitment Theory}

The stakeholder commitment theory relies on the idea that corporations have a moral commitment to their stakeholders (Freeman \& Harrison, 1997). Stakeholder, in this context, refers to any person or entity that will be affected by the actions of the Mines. Those that view CSR through the lens of this theory model believe that these programmes are the result of voluntary actions and that corporation is not solely, profit oriented and hence, will still give to the society willingly without any legal instrument mandating them to do so.

AngloGold Ashanti Obuasi Mines considering human rights and social justice, does not impose CSR programmes against the real needs of the people but considers and involves them in the formulation and implementation of these programmes, after host communities make proposals to them in need of certain amenities and other social interventions. Ghana has recently developed a legal instrument towards enhancing CSR among companies; AGA Obuasi Mines is still committed to fully enhancing the welfare of the people in Obuasi despite decline in productivity and gain of revenue due to the fluctuations on the international price of gold as well as any legal instrument which obliges them to give back to the society in which it operates.

\section{Methodology}

\subsection{Research Strategy and Design}

This study pursues a qualitative strategy with a single case design. The study also employed action-participatory based research in collection of data. It adapted action participatory based form of research because it would involve people in some communities in the collection of data. The study adopts a single case study design, with the area of study being Obuasi municipality and hence, findings cannot be generalized for other gold mining towns in Ghana either than Obuasi municipality (Anol, 2012).

\subsection{Methods for Data Collection}

This included questionnaire surveys, informal interviewing of senior staff members of AngloGold Ashanti, some members of certain allocated communities in the AGA catchment area, as well as heads of some government institutions in the Obuasi municipality.

Stakeholder or public participation is one of the key instruments used in the development of comprehensive and sustainable programmes by AngloGold Ashanti (AGA Annual Report, 2013). Public participation is embedded in the concept of sustainability as well as cycle of corporate social responsibility since all actions are going to affect third parties, requiring that all relevant stakeholders are brought on board initiating of projects and their implementation (Marrewijk, 2003).

AGA is a profit oriented multinational company that extracts natural resources, process and exports these minerals to gain revenue. AGA's activities have a significant impact on the environment, health and socio cultural lives of the people in Obuasi and its environs. Some of these impacts are seen with traces of cyanide found in the Kwabrafo River a decade ago after refining the mineral, fumes from the PTP plant at Sampsonkrom, Ahansonyewodea and other communities polluting the air, thereby causing skin irritation problems on people in some of these communities (Akabzaa \& Darimani, 2001). No proper consultation and participation were done years back and this created a lot of issues between the mines and some host communities. Hence, as they take from the society, they give back to the society what they take by adhering to CSR programmes, initiated to enhance the socio-economic welfare of the Obuasi municipality (Akabzaa et al., 2006).

\subsection{Sampling Size}

Twelve respondents were interviewed to gather information. The study adopts to purposive sampling technique because the respondents selected were deemed knowledgeable in relation to the study area (Nunoo, 2013). These respondents were selected based on their knowledge on the aim and objectives of the study, outlined in section 1.0 as far as the welfare of the people and community are concerned. Of the 12 respondents, 10 were males, in addition to two females. An average of 45 minutes to an hour was spent per questionnaire interview, whereas other respondents did not have a stipulated time limit. The 12 respondents consisted of traditional and youth leaders in certain communities, thus, Chiefs and some opinion leaders, senior staff and directors of the Obuasi municipal Assembly Planning and Co-coordinating Department, the Auditor General's Department, Municipal Health Directorate and some assemblymen in certain communities in the Obuasi municipality. The 12 respondents selected for the study were selected because CSR is very technical and were deemed knowledgeable 
to give adequate information to the subject matter. These 12 respondents had four (4) having their age range between 25-40 years. The remaining eight (8) respondents had their ages being above 40 years with none of these respondents being disabled.

\subsection{Data Analysis}

The analysis of the results included transcription of the questionnaires and the analysis of the data together with information in company reports and other secondary data, as well as information obtained through personal observation. Personal observations were made to verify the survey information and the content of the company's annual reports.

\subsection{Limitation of the Study}

Some challenges were encountered during the collection of data. Some of these challenges encountered were some community leaders not willing to give out information. They felt they had always complained to AGA to meet out the terms they agreed upon after these programmes were formulated and yet have not been fulfilled.

One other challenge encountered was an issue of time. Some of these elite interviewed at their workplaces were informed prior to their own stipulated time they gave yet were occupied. Some of these community leaders interviewed were mostly farmers, and usually came home late in the course of the day. Some had to go to the extent of requesting for funds before giving out information.

Others on the other hand, were not willing to give in depth information on issues that stems their society because they had some agreements with AGA on information.

\section{Results and Discussions}

This section describes stakeholder participation and sustainability of corporate social responsibility programmes in Ghana: case study of AngloGold Ashanti in Obuasi.

\subsection{Stakeholder Participation in Developing Corporate Social Responsibility Programmes by AngloGold Ashanti-Obuasi}

\subsubsection{Community Involvement and Stakeholder Composition}

The principal stakeholders of AGA are employees, their families, and employee representatives, communities in which AGA-Obuasi mines operate, business partners, shareholders, governments and other stakeholders (AGA Annual Report, 2013). According to the head of Social and Community Development Centre, 63 communities in the Obuasi municipality are covered in the engagement plan, comprising 32 Community Consultative Committees (CCC), including Artisanal Miners' Association and local NGOs/CBOs groups. Meetings are normally scheduled to interact with the federal government and municipal authorities, civil society organizations, NGO's and other stakeholders. Data collected from AGA stated that, three (3) CCC meetings and one (1) community forum are held each week and each CCC group meets at least 5 times in a year. Averages of 124 out of 151 meetings are held each year representing about $88.2 \%$. CCC membership consists of the local chief and two of his traditional elders/opinion leaders; the Assembly member who is also a representative of the District/Municipal Authority; the local government Unit Committee Chairperson and Secretary of the local government, and two women and male youth representatives each. After conducting interviews with some community heads in some communities like; Dokyiwa, Mangoase and Apitikooko, it was affirmed that, such meetings were frequently held with relevant stakeholders involved in the formulation of these programmes in some allocated communities in the Obuasi Municipality.

The head of the Social and Community Development Center emphasized that AGA-Obuasi does not initiate any project without consulting the stakeholders identified above. He said that the various projects being undertaken in various communities were initiated upon request from those communities. Hence, whenever proposals are submitted by these communities, they sit down with AGA-Obuasi top management to analyze and draw up a plan to assist these communities since they have to develop the area in which they operate in line with their strategic policies.

\subsubsection{Mode and Level of Community Involvement \& Setting of Priorities}

We found that, consultative meetings are held with the relevant stakeholders to determine the real needs of the people rather than the needs identified during consultative meetings. Another meeting is held once or twice with the people in communities to determine if those proposals represent the real needs of the people. Hence, various projects under the CSR initiative in various communities are considered and implemented upon request. Based on the information gathered through questionnaires and informal interviews, some assembly members and traditional leaders confirmed the fact that, those projects initiated by AGA are implemented upon request from 
host communities. They also highlighted the fact that, the leaders and members of the community are engaged through the Consultative meetings. The assembly member for Ampunyase electoral area (Apitikooko) affirmed this fact but stated that community meetings in his and several other communities were poorly attended. This was also affirmed by the Chief of the new Dokyiwa community as well as some youth within the community. Hence, the community meetings are not held frequently as stated in AGA's report and attract few community members in most areas.

Questionnaire results show that 11 out of the 12respondents, which included two heads of academic institutions, five assembly members, a chief, two youth leaders and the municipal planning coordinator, stated that AGA involved communities in the formulation and implementation of CSR programmes through Consultative Committee meetings. One of them stated that he wasn't clear about the mode through which they involve communities in implementing these projects. The next section discusses the sustainability of CSR projects/programmes initiated by AGA.

\subsection{AGA-Obuasi's CSR Programmes}

CSR programmes initiated by AGA-Obuasi are categorized into four main areas: Community Health and Malaria Control Programme, Social Infrastructure, Education and Sports as well as Art, Culture \& Heritage programmes. According to head of the Social and Community Development Centre at AGA-Obuasi, Corporate Social Responsibility programmes which are being initiated by AGA-Obuasi fall into two main themes: roll-out programmes and one-time projects. The roll-out projects are mostly programmes whereas the one-time are mostly projects. These roll out and one-time projects initiated under CSR are being categorized by AGA. Hence, per the results obtained from questionnaires administered and some interviews conducted, the study would delve into how sustainable these projects classified under roll out and one-time projects would be, if AGA closes down. These programmes initiated by AGA are important because, they tend to enhance the socio-economic welfare of the people in Obuasi and the municipal as a whole.

Roll-out programmes: The following programmes are being initiated under the roll-out phase:

The alternative livelihood project which entails- the Garment Project and the Piggery Project, the Community Sanitation Programme, The malaria control programme, scholarships for employee wards, health care for employees at AGA hospital, and free utility services for the people of Sanso and Anyinam communities.

One- time projects: The following projects are being initiated under the one-time phase; Donation of school buses to some schools in the Adansi District, construction and renovation of schools in the Obuasi Municipality, construction and upgrading of roads in Obuasi, construction of AGA hospital to serve the entire Obuasi municipality and staff members, provision of electricity poles for some communities in Obuasi, drilling of boreholes in some communities, provision of desktop computers and accessories to some schools in Obuasi, and fencing of schools at Mangoase and Anyinam communities.

These programmes and projects are classified into roll out and one time projects by AGA. These were known after conducting an interview with the head of the social and community development center at AGA. These projects classified under Roll out and one-time have also been outlined in AGA's 2013 Annual Report in a section entitled "Sustainability and Community Development".

\subsection{Sustainable CSR Programmes in Relation to Rolled-Out \& One-Time Projects}

As stated in the objectives, in section 1.0 of this study, "Sustainability" is a key feature of the AGA-Obuasi CSR programmes. The issue of sustainability of these CSR programmes as stated in the objectives is based on how these programmes and projects are going to run or continue if the AngloGold should shut down. Ten (10) of the twelve (12) respondents responded in the questionnaire that the CSR projects/programmes would not be pursued should the mines close down its production or operations. The two remaining respondents stated emphatically that these programmes/projects would be pursued. Upon further discussions the 10 respondents who said the projects wouldn't be pursued didn't provide much insight into CSR projects initiated by AGA in relation to their sustainability. Interviews with some municipal assembly personnel and some beneficiaries of the alternative livelihood projects revealed that, not all the CSR projects/programmes which are initiated by AGA-Obuasi are sustainable. Analysis of the data collected from the respondents and several interviews conducted by AGA-staff and research personnel showed that almost all the one-time or quick projects are sustainable.

These projects are sustainable in the sense that, in case the mines close down its operations, they would still be pursued. These one-time projects like; Schools, Community centers, Roads constructed to link rural areas to the city and so on, are being handed over to the municipal assembly or government and hence, would still be pursued. This way, the government takes full responsibility and mandates people to manage it. In addition, the 
alternative livelihood projects which entail; the garment and piggery projects were initiated by AGA to create more jobs for the people and also to improve the standard of living are also sustainable. The garment project is being manned by community personnel, who have specialized in tailoring and other occupations and provides about 10,000 aprons to AGA-Obuasi and other business organizations. Should the company close down, they would still carry on with their business as the program has been handed over to them. The only problem would be a decrease in revenue since they are the main supplier of aprons to AGA-Obuasi and should the mines close down; they would lose such revenue, earned from supplying aprons to the mines. Upon examining research data and results obtained after conducting interviews with the head of the Social Development Center, some other senior staff of AGA-Obuasi and beneficiaries of the project upon personal inspection concluded that, these projects or programmes outlined in the one-time projects are sustainable because those projects have been handed over to the government.

The piggery project, initiated by AGA-Obuasi to impart livelihood skills among people in the four allocated communities (Mampamhwe, Jimisokakraba, Ahasonyewodea andAdaase) is also sustainable. This project was handed to some families in these allocated communities to man this project and help improve their welfare by providing meat for the market and generate revenues, among others. Families who are beneficiaries of these programmes received training through capacity building programmes, with some funds allocated to them.

Moreover, the community sanitation project which was also initiated by AGA-Obuasi to help improve upon sanitation in Obuasi and its environs is also sustainable. The programme was handed over to the municipal assembly lately despite the fact that AGA was funding it by paying off workers within this project as well as providing them with some equipment. Hence, should the mines close down; the assembly can still manage this programme effectively.

\subsection{Unsustainable CSR Programmes Initiated by AGA-Obuasi.}

The malaria control programme (MCP), which was initiated by AGA-Obuasi and assisted by the Global Fund, is a self contained program which extends to other parts of the country, especially the northern regions of Ghana aside from Obuasi. The malaria control programme is heavily financed by AGA in the Obuasi community despite being assisted by the Global Fund. Should the mines close down, the programme maybe heavily affected even if the Global Fund continues to fund it due to the large amount of funds provided by AGA, Hence, the programme which has helped to reduce malaria by $76 \%$ over the past 10 years (AGA, Annual Report, 2013) may collapse should the mines close down their operations, unless the Global Fund would be willing to finance the whole programme.

On the other hand, free utility services, including electricity and water for Anyinam and Sanso communities, are not sustainable in the sense that they are being pursued as operations still in progress. These communities are provided with these services because they were heavily affected by operations of the mines and hence, these services are being provided to compensate them. In case operations close down; AGA-Obuasi may not foot the bills for the services provided, rendering the provisions of free utility services for these communities unsustainable. In addition, scholarships for employee wards and needy students in some communities or schools are not sustainable because they too are financed exclusively by AGA-Obuasi.

\section{Recommendations}

The main aim of the study is to assess stakeholder participation and sustainability of corporate social responsibility programmes initiated by AngloGold Ashanti in Obuasi, Ghana. Stakeholders are fully involved in the formulation and implementation of CSR programmes and although much has been achieved, lot more has to be done to make this concept effective. Hence, the following measures can be considered to enhance the concept of CSR;

CSR policy and laws for Ghana: Many laws exist in Ghana for the regulation of corporations. However, these laws hardly contain any progressive provisions for CSR, thus, laws that directly require businesses to be responsible. It is recommended that a CSR policy be developed for Ghana and that the laws that regulate the various sectors of the economy, in Ghana are amended to include specific CSR provisions. CSR principles are stated in some laws including the National Land Policy, the National Youth Policy and the National AIDS Policy. Hence, it is important that, the CSR principles stated in these laws are enforceable.

Advocacy for CSR: Ghana needs to draft legislation and policies supported by major advocacy efforts to make CSR effective, as in other countries. Policies, legal and regulatory frameworks for CSR will need to be reviewed periodically. Corporations must report on CSR and sensitize the public as well as support communities through social program. Corporations must implement sustainable CSR initiatives such as; training, apprenticeships and 
skills development in the communities in which they operate to impart on youth livelihood skills that can improve their livelihood and that of the community as a whole.

Exemptions and reductions of taxes for some corporations: Exemptions or reductions in taxes through negotiations with government can help some of these companies to contribute to the socio-economic welfare of the communities in which they operate. The private sector is the engine of growth for most economies and can provide basic infrastructure as well as create employment opportunities. Hence, the government can incorporate some of these factors to make CSR being a voluntary initiative very effective in the country in our quest to attain development in a more sustainable manner.

\section{Conclusions}

Corporate Social Responsibility (CSR) is an entry point for understanding sustainable development issues which encompasses several sectors. In Ghana and other developing countries, CSR has been identified as one of the most instrumental and pragmatic tools to attain sustainable development but may lead to uneconomic use of scarce resources in the economy if policies are wrongly implemented.

CSR programmes initiated by AGA-Obuasi are categorized into four main areas, thus, Community Health \&Malaria Control Programme, Social Infrastructure, Education, Youth \& Sports, Art; Culture \& Heritage which are further classified into rolled-out and one-time programmes. Activities of the mines affect Obuasi and its allocated unit areas environmentally, socially, economically and culturally and hence, the company is not only profit oriented but has assumed responsibility of developing the community through CSR and the reclamation bond or process.

CSR programmes are undertaken voluntarily by the mines to facilitate its operations. CSR policies, plans, program and projects are broad and hence, the study was conducted to assess stakeholder participation and sustainability. The relevant stakeholders in various communities in the AGA-Obuasi operational area are involved in the formulation and implementation of CSR programmes through consultative committee meetings, community/public meetings in various allocated communities. Program are formulated and implemented based on request from host communities.

Most of the CSR projects initiated by AGA-Obuasi are sustainable with few program under CSR not being sustainable. Among these are; provision of free utility services to some communities like; Anyinam and Sanso, the malaria control program and scholarships being awarded to employee and some wards of certain community members.

CSR initiated by AGA per data gathered shows that, these programmes are formulated and initiated based upon request from these communities in Obuasi. Despite these, CSR programmes do not cover all the needs of the people. For instance; the people of New Dokyiwa through interviewing, said they were resettled from their old community because they were heavily affected by the operations of the Mines. Although AGA has improved upon some aspects of their social life through the provision of a community center, construction of a school and a church for them in their new community. The community still lacks a chief's palace, a market for economic activities, limited farms for agriculture which they had in their previous community. Some other communities stated that, AGA is yet to fulfill some terms which they agreed upon, with the aim of enhancing the welfare of people living in these communities in the Obuasi municipality.

There is no comprehensive or readily available document on the experiences and achievements of CSR in Ghana. Nonetheless, a variety of policies, laws, practices and initiatives that could provide the CSR regulatory framework are available in the country (Atuguba \& Dowuona, 2008). For instance, a number of governmental policies, including the Ghana Land Policy Document, bear directly on CSR, both positively and negatively. Along this line, Ghana has taken up the initiative to make CSR effective and beneficial to communities under the premise that, companies would not only be profit oriented but also contribute to the growth and development of the areas in which they operate. CSR can strengthen the socioeconomic relationship between corporations with society, by helping corporations to align their values with societal expectations, in order to avoid conflicts and reap tangible benefits. AngloGold Ashanti-Obuasi (AGA) has undertaken this voluntary initiative and was ranked Gold in that category (EPA-Akoben, 2013). This study has shown CSR promises to be an effective entry tool to sustainable development linked with the operations of corporations.

\section{Acknowledgements}

The authors would like to acknowledge the support provided by Management Department of AngloGold Ashanti Company Limited-Obuasi, the Head of the Social and Community Development Centre, Management Training Centre, Obuasi Secondary Technical School, a cluster of schools at community called Mangoase, Methodist 
Primary and Junior High School at Anyinam, Obuasi Municipal Assembly Planning Co-ordinator \& Director, Auditing Department in Obuasi, the Assemblyman at Apitikooko, as well as the chief and people of New Dokyiwa community.

\section{References}

Akabzaa, T. (2006). Impact assessment of mining activity of the Adansi West District (Obuasi) and Surrounding areas. Third World Network (TWN).

Akabzaa, T., \& Darimani, A. (2001). Impacts of mining sector investments in Ghana. A study of the Tarkwa mining region (draft report). Retrieved March 24, 2014, from www.saprin.org/ghana/research/gha mining.pdf

AngloGold Ashanti. (2007). Country Report, Ghana.

AngloGold Ashanti. (2013). Trust Fund Staff Training, Obuasi. Ghana.

Atuguba, R. (2006). CSR in Ghana, Final Report, Friedrich Ebert Stiftung (FES. Accra: Ghana).

Bhattacherjee, A. (2012). Social Science Research: Principles, Methods \& Practices. Creative Commons Attribution, University of Florida-Tampa, USA.

EPA. (2013). Environmental Performance Rating \& Disclosure System-AKOBEN. Ghana.

Ghana Statistical Service. (2012). 2010 Population \& Housing Census. $31^{\text {st }}$ May 2012, Ghana.

Harrison, J. S., \& Freeman, R. E. (1999). Stakeholders, social responsibility, and performance: Empirical evidence and theoretical perspectives. Academy of management Journal, 42(5), 479-485.

Hohnen, P. (2007). Corporate Social Responsibility, An implementation Guide for business. International Institute for Sustainable Development, Canada.

Idemudia, U. (2007). Corporate Partnership \& Community Development in the Nigerian Oil Industry. Strengths \& Limitations, Markets, Business and Regulation Programme Paper No.2. United Nations Research Institute for Social Development.

Mark W. M., \& Jo, M. C. V. E. (2012). Corporate Sustainability Management, The art and science of managing non-financial performance. Earthscan publishing for Sustainable Future, London \& New York.

Marrewijk, M. V. (2003), Concepts \& Definitions of CSR \& Corporate Sustainability between Agency \& Communion. Journal of Business Ethics, 44(2), 95-105.

Nunoo, E. (2013). Introduction to Research Methods \& Proposal Writing I. Edsam Printing Press, Appointed Helpers Educational Series, Central University College, Accra.

World Business Council for Sustainable Development. (2000). Corporate Social Responsibility: Making Good Business Sense. Geneva, Switzerland.

\section{Copyrights}

Copyright for this article is retained by the author(s), with first publication rights granted to the journal.

This is an open-access article distributed under the terms and conditions of the Creative Commons Attribution license (http://creativecommons.org/licenses/by/3.0/). 